\title{
South Carolina Coastal Erosion Study
}

\section{Introduction}

Much of the South Carolina coast is heavily developed, supporting local populations, infrastructure, and a large tourism industry. Local economies are greatly affected by damage and property loss due to coastal erosion, which occurs primarily during severe storm events. In 1989, Hurricane Hugo caused over $\$ 5$ billion in damages to coastal residences and industry. Understanding the factors controlling coastal erosion, sediment transport, and shoreline change is essential to the successful management of coastal resources.

In 1999, the U.S. Geological Survey (USGS), in partnership with the South Carolina Sea Grant Consortium, began a study of processes affecting shoreline change along the northern coast of South Carolina, focusing on the Grand Strand

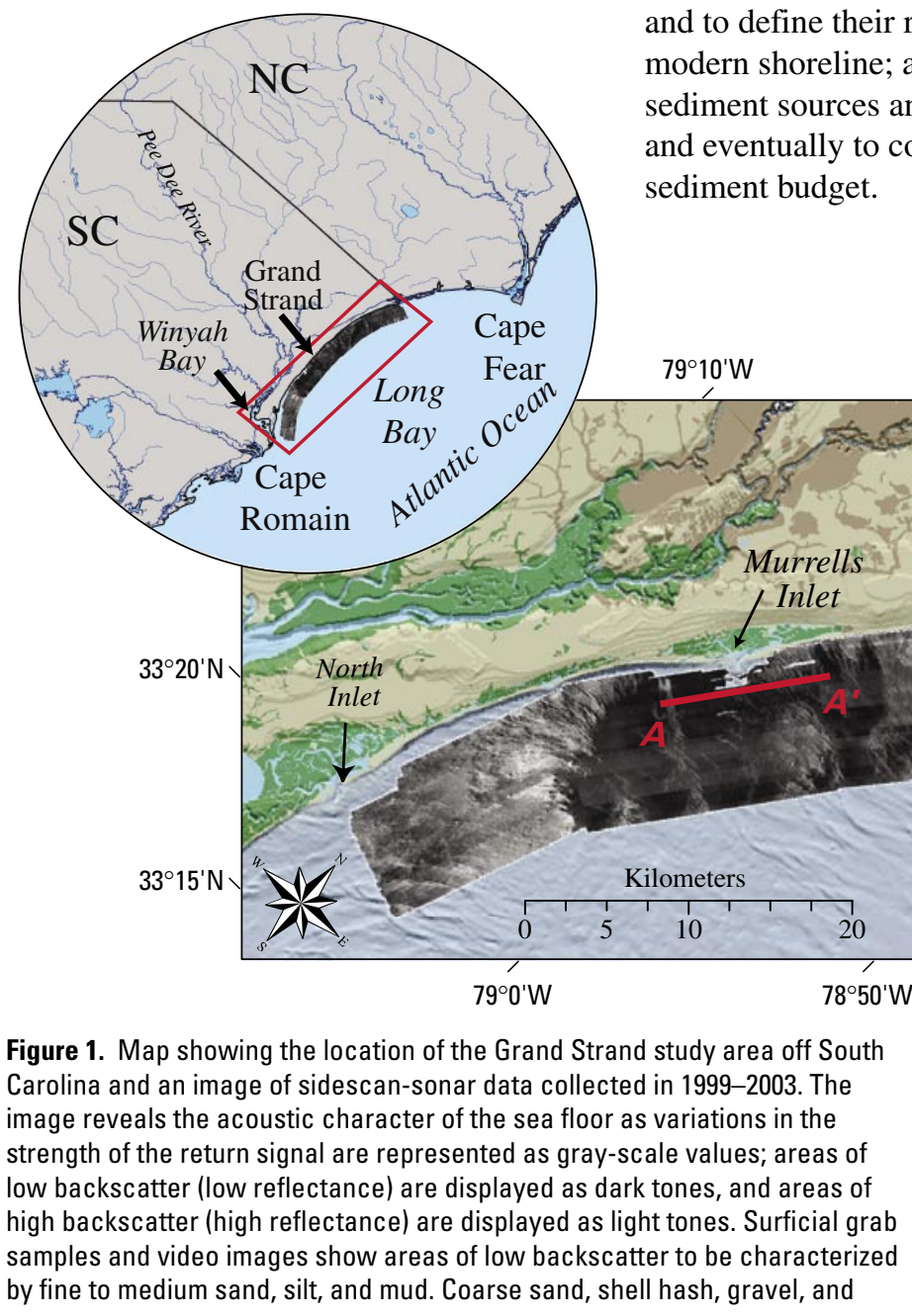

region (fig. 1). Previous work along the U.S. Atlantic coast shows that the structure and composition of older geologic strata located seaward of the coast heavily influence the coastal behavior of areas with limited sediment supply, such as the Grand Strand. By defining this geologic framework and identifying the transport pathways and sinks of sediment, geoscientists are developing conceptual models of the present-day physical processes shaping the South Carolina coast.

The primary objectives of this research effort are (1) to provide a regional synthesis of the shallow geologic framework underlying the coastal upland, shoreface, and inner continental shelf and to define its role in coastal evolution and modern beach behavior; (2) to identify and model the physical processes affecting coastal ocean circulation and sediment transport and to define their roles in shaping the modern shoreline; and (3) to identify sediment sources and transport pathways and eventually to construct a regional sediment budget.

\section{Geologic Mapping}

South Carolina's Grand Strand is centered on a 100-kilometer (km)-long arcuate stretch of shoreline within the apex of Long Bay (fig. 1). Unlike the sandy barrier beaches that characterize most of the U.S. Atlantic margin, the central part of the Grand Strand is a mainland beach, not backed by an estuary. Numerous borings in onshore coastal plain deposits have identified younger Holocene beach deposits (formed $\sim 10,000$ years ago to present) that are attached to older Pleistocene headlands (ice-age deposits formed 1.8 million to 10,000 years ago) in this region (fig. 2). These relict headlands most likely formed at a slightly higher sea level and continue to influence the shape of the shoreline today as sea level rises toward its former highstand position. To the north and south of Myrtle Beach, several small barrier islands with relatively large tidal inlets are separated from the older Pleistocene mainland by narrow, marsh-filled estuaries. outcropping strata characterize areas of high backscatter. $A-A^{\prime}$ marks the location of the seismic profile displayed in figure 3 . The offshore sand body oriented oblique to the shoreline is a potential source of beach-nourishment material. The base map was compiled from bathymetric and topographic data from the National Geophysical Data Center (NGDC) U.S. coastal relief model. Vertical exaggeration (25x) and an illumination source were applied to the data, yielding shaded-relief images. The dark-blue line parallel to the shore is an artifact of data processing. 
High-resolution geophysical systems (sidescan sonar, swath bathymetry, and seismic reflection) were used to map the surficial and subsurface, or framework, geology of the inner continental shelf in water depths ranging from 4 to 14 meters (m) (fig. 1). These acoustic data define the distribution of surficial sediment (mud, sand, gravel, and rock), the geomorphology, or shape, of the seabed, and the stratigraphy and structure of units underlying the inner shelf. The surveys extend $10 \mathrm{~km}$ seaward of the coast and include sediment sampling, bottom video, and photography to calibrate or verify the geophysical data.

Sea-floor mapping reveals a generally sediment starved, low-relief inner shelf that dips gently seaward. Extensive areas lack significant sediment deposits and are characterized by high backscatter on the sidescan-sonar imagery (fig. 1). Seismic-reflection data show Cretaceous/ Tertiary strata (pre-ice-age deposits formed 145 to 1.8 million years ago) that are folded, dipping to the southeast, and locally incised by a network of filled paleochannels cut by the ancestral Pee Dee River during previous sea-level lowstands (fig. 3). The location and trend of the channels appear to be controlled by differential erosion of the underlying strata. The younger channel-fill deposits and older underlying units are truncated by a regional unconformity (gap in the geologic record due to erosion or nondeposition) that was eroded during multiple sea-level cycles.
A patchy, discontinuous veneer of low-backscatter, relatively well sorted, fine to medium sand overlies this flatlying, erosional surface (figs. 2 and 3). Small channels observed within this veneer likely represent remnants of tidal inlets in a barrier-island chain that formerly existed seaward of the modern coast. The thickness of sand deposits overlying the erosional surface is variable; large accumulations, locally more than $6 \mathrm{~m}$ thick, generally are found in tidal-delta complexes near modern inlets (figs. 2 and 4). One exception is a large shore-oblique sand body offshore of Myrtle Beach, which is not associated with a modern inlet (fig. 4). The sand deposit is $10 \mathrm{~km}$ long, $2 \mathrm{~km}$ wide, and more than 3 $\mathrm{m}$ thick; it represents a potential source of beach-nourishment material.
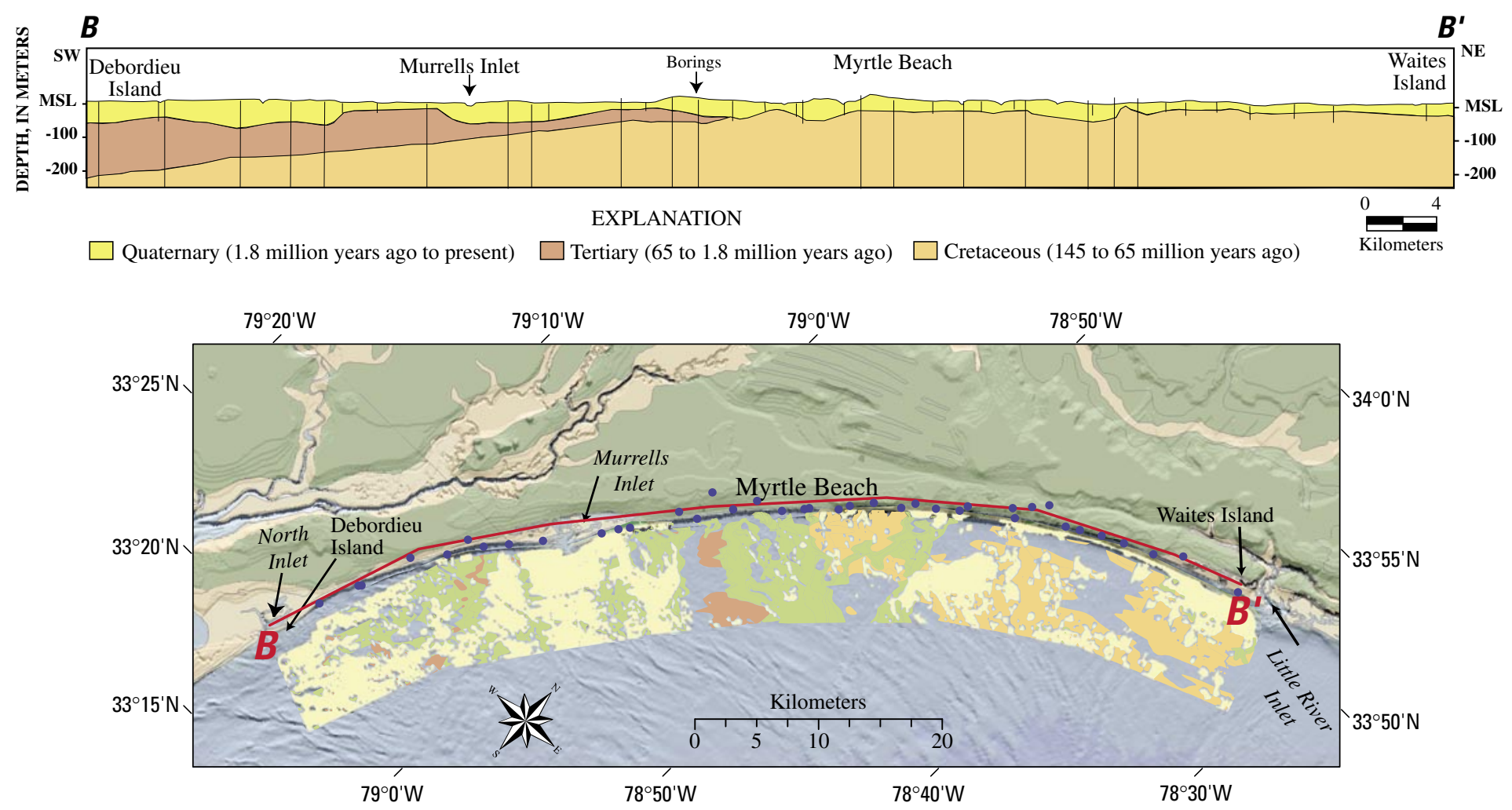

\section{OFFSHORE GEOLOGY}

Holocene (10,000 years ago to present)

Pleistocene (1.8 million to 10,000 years ago)

Tertiary (65 to 1.8 million years ago)

Cretaceous (145 to 65 million years ago)

No penetration

Figure 2. Geologic cross section $B-B^{\prime}$ and map of the Grand Strand area, South Carolina, displaying onshore and offshore surficial geology and locations of coastal plain borings. Data from the borings were used to generate the geologic cross section. Surficial geologic maps indicate that older Pleistocene deposits compose the mainland beaches along the Grand Strand. These relict deposits were formed when sea level was higher than the present level and continue to influence the shape of the modern shoreline as sea level rises. Younger Holocene deposits are generally centered on modern inlet systems. Cross section modified from Putney and others (2004); onshore geology modi- fied from McCartan and others (1984) and Owens (1989). The offshore surficial geology was defined through seismic profiles. Older Cretaceous folded and dipping strata rise close to the sea floor in the north, indicating an absence of younger units in this region. The Cretaceous strata deepen to the south, as evidenced by younger Tertiary and Pleistocene deposits in the middle and southern regions of the survey area. Younger Holocene sediments are primarily located near modern inlets. An exception is the sand body lying oblique to the coast offshore of Myrtle Beach (see fig. 4). Geologic ages modified from International Commission on Stratigraphy (2004). MSL, mean sea level. 


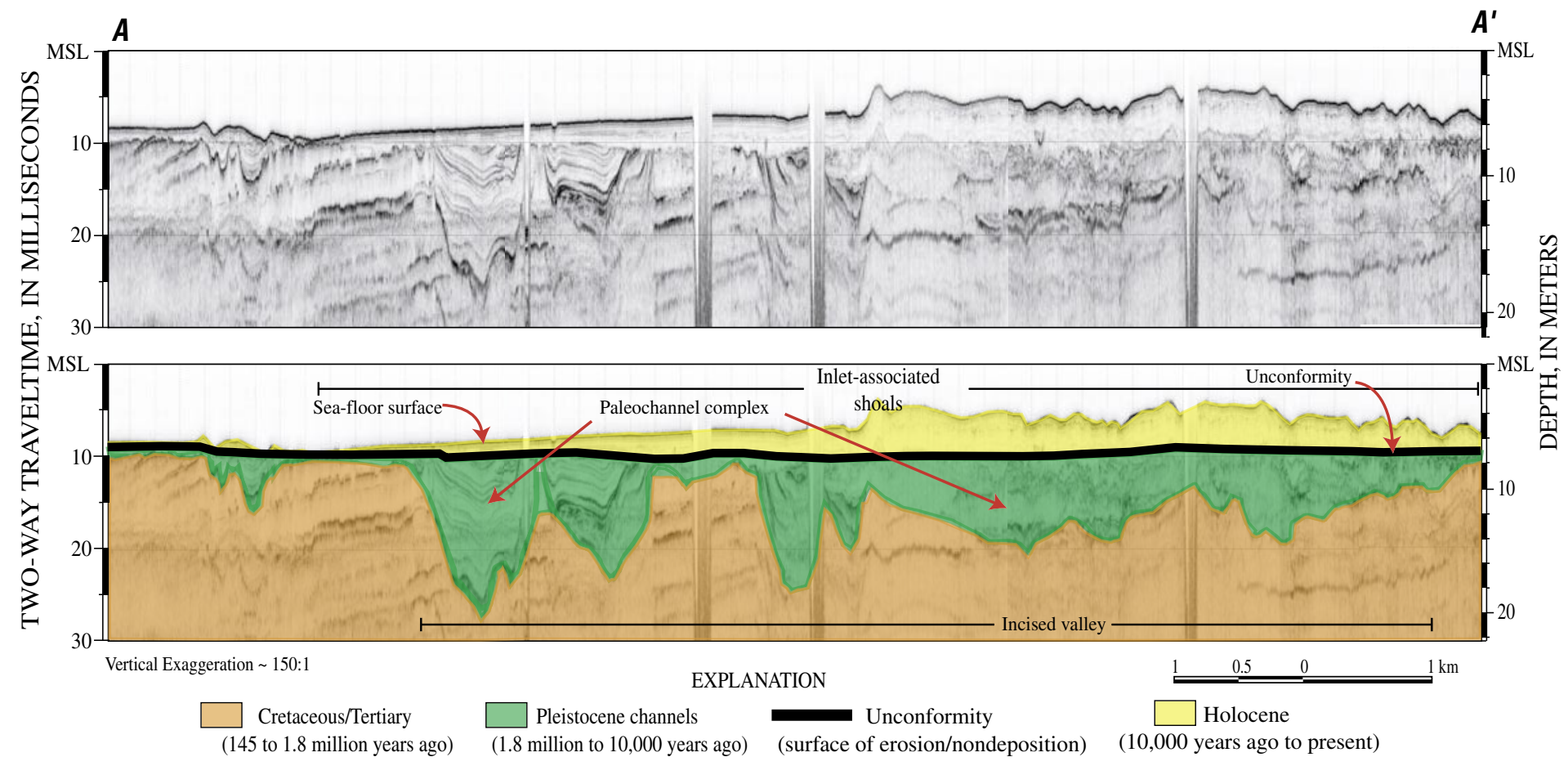

Figure 3. Interpreted (bottom) and uninterpreted (top) versions of a representative seismic profile collected offshore of Murrells Inlet, S.C. Older Cretaceous/Tertiary units are incised by Pleistocene (ice-age) paleochannels formed by the ancestral Pee Dee River during sea-level lowstands. The channels are truncated by an unconformity eroded during multiple sea-level cycles. A patchy, discontinuous veneer of younger Holocene sediments overlies the unconformity. Vertical scale is displayed as twoway traveltime in milliseconds and approximate depth in meters below mean sea level (MSL); depth is calculated by assuming 1,500 meters per second for the speed of sound in water. See figure 1 for location.

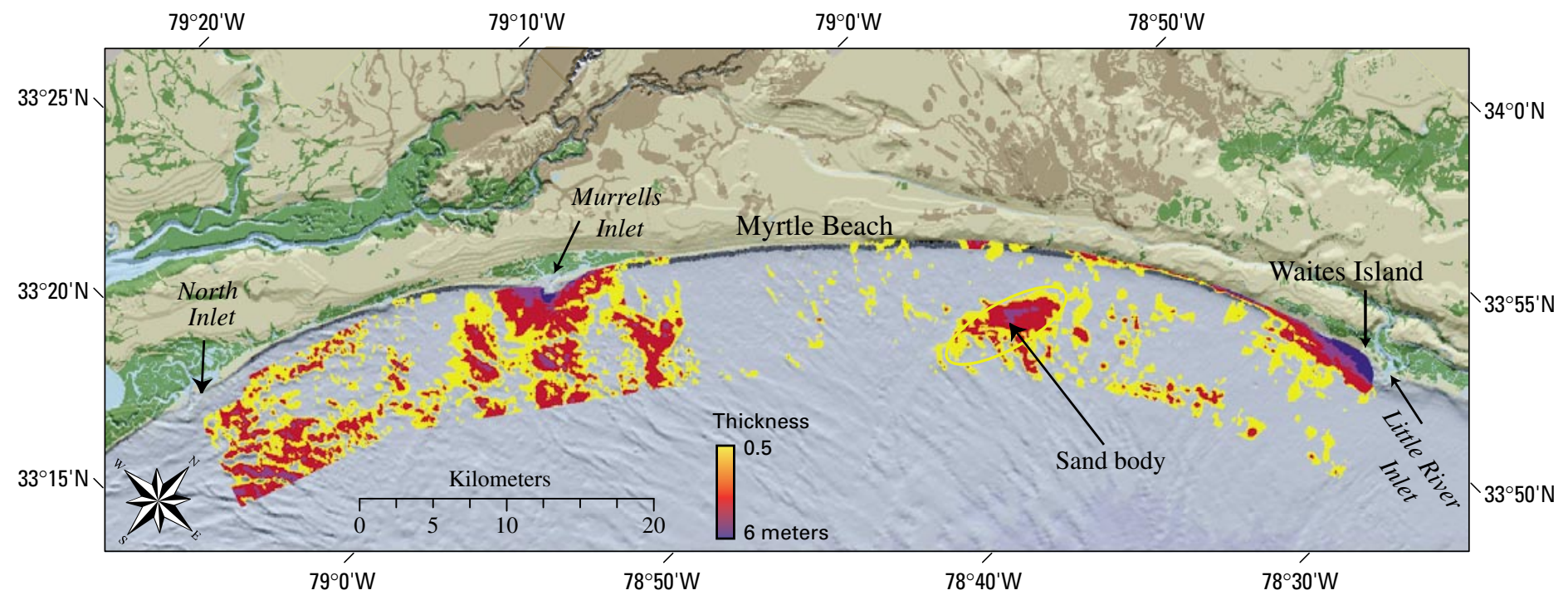

Figure 4. Map of the Grand Strand area, South Carolina, displaying the thickness of offshore Holocene sediment as defined through seismic profiles. Sediment thickness ranges from 0.5 to more than 6 meters, and the thickest deposits are near tidal inlets. An exception is the sand body lying offshore of Myrtle Beach, which is a potential source of beach-nourishment material. Cretaceous/Tertiary strata and (or) Pleistocene deposits are at or near the sea floor in regions devoid of Holocene sediment or overlain by a thin veneer of sediment (displayed as areas of no color). Sediment thickness less than $0.5 \mathrm{~m}$ was not resolved by the seismic system. 


\section{Study of Present-Day Physical Processes}

Insights derived from the geologic framework studies have guided oceanographic experiments to better understand the transport of sediment within Long Bay (fig. 1). These studies aim (1) to measure and model the oceanographic circulation in the region, (2) to identify the processes maintaining the offshore sand body, (3) to quantify changes in wave energy propagation in the nearshore due to the presence of this sand body, and (4) to identify the consequences of removal of the sand body.

To accomplish these goals, oceanographic and sediment-transport observational systems (fig. 5) were deployed for a period of 6 months (November 2003 to April 2004) at eight sites to measure pressure, currents, salinity, temperature, suspended-sediment concentrations, and wave characteristics. Initial results show that local wind events strongly correlate with peaks in wave energy. Winds also drive near-surface currents. However, bottom currents near the sea floor are more complex and are controlled by a combination of wind forcing, upwelling or downwelling flows, and stratification. Additionally, local waves provide energy that resuspends bottom sediments, which have increased concentrations in the water column during strong wind events. This combination of wind-driven surface currents and near-bottom circulation determines the direction and magnitude of sediment transport within Long Bay.

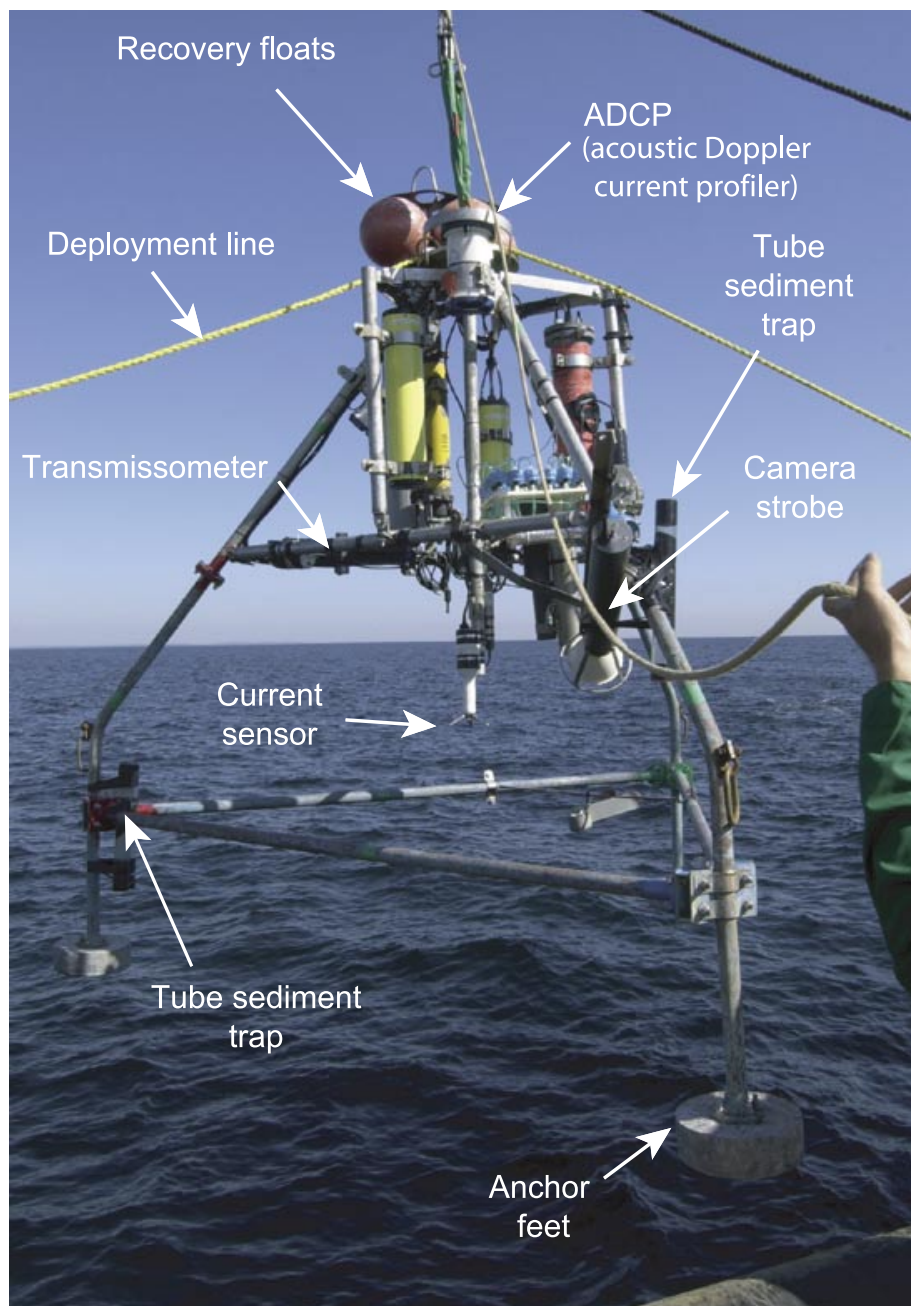

Figure 5. Deployment of a USGS tripod used for oceanographic studies. The tripod is configured with various instruments used to measure pressure, currents, salinity, temperature, suspended-sediment concentrations, and wave characteristics. Photograph by Dann Blackwood (USGS).

\section{Sediment Budget}

Defining the transport rates and volumes of sediment that enter and leave a segment of coast is critical to the effective management of coastal areas. Geomorphic evidence suggests that erosion of the inner shelf contributes sandy sediment to the coastal system. Integrating oceanographic studies and geologic mapping will yield a comprehensive view of the physical processes shaping the modern shoreline and, ultimately, will define the regional sediment budget for the Grand Strand.

\section{References Cited}

International Commission on Stratigraphy, 2004, International stratigraphic chart: available online at http:// www.stratigraphy.org/chus.pdf

McCartan, Lucy, Lemon, E.M., Jr., and Weems, R.E., 1984, Geologic map of the area between Charleston and Orangeburg, South Carolina: U.S. Geological Survey Miscellaneous Investigations Map I-1472, 2 sheets, scale 1:250,000.

Owens, J.P., 1989, Geologic map of the Cape Fear region, Florence $1^{\circ} \times 2^{\circ}$ quadrangle and northern half of the Georgetown $1^{\circ} \times 2^{\circ}$ quadrangle, North Carolina and South Carolina: U.S. Geological Survey Miscellaneous Investigations Map I-1948A, 2 sheets, scale 1:250,000.

Putney, T.R., Katuna, M.P., and Harris, M.S., 2004, Subsurface stratigraphy and geomorphology of the Grand Strand, Georgetown and Horry Counties, South Carolina: Southeastern Geology, v. 42, no. 4, p. 217-236.

By Jane F. Denny, Wayne E. Baldwin, William C. Schwab, John C. Warner, and M. Richard DeVoe

\section{For more information, please contact:}

Jane F. Denny

William C. Schwab

U.S. Geological Survey

384 Woods Hole Road

Woods Hole, MA 02543-1598

Telephone: 508-457-2311 (Denny) 508-457-2211 (Schwab)

E-mail: jdenny@usgs.gov bschwab@usgs.gov

Web site: http://woodshole.er.usgs.gov/

M. Richard DeVoe

South Carolina Sea Grant Consortium

Charleston, SC 29401

E-mail: Rick.DeVoe@ seagrant.org 